\title{
Biogeochemical activity in arsenic prone zone
}

\author{
Debashis Chatterjee ${ }^{1}$, Pinaki Ghosh $^{1}$, Shilajit Barua ${ }^{2}$ and Aishwarya Mukherjee ${ }^{3}$ \\ ${ }^{1}$ Department of Chemistry, University of Kalyani, India \\ ${ }^{2}$ Department of Microbiology, Vijaygarh Jyotish Ray College, India \\ ${ }^{3}$ Hoogly Engineering and Technology College, Vivekananda Road, Pipulpati, Hoogly, India \\ Submission: December 14, 2016; Published: January 17, 2017 \\ *Corresponding author: Pinaki Ghosh, Department of Chemistry, University of Kalyani, Nadia-741235, West Bengal, India
}

\begin{abstract}
The world's largest arsenic (As) mass poisoning have been reported from West Bengal, India in early eighties.. Arsenic as a Heavy metals are the natural constituents of the earth crust. The level of As have been found to be particular alarmining in India, Bangladesh, China, Taiwan, United states and many other countries. The health risks of As exposure due to the installation of thousand of shallow tube wells in Bengal Delta Plain (BDP) is known, However, microbial contamination of shallow aquifer is another important issue that can be linked with As mobilization and water quality. Different types of Bacteria influence As geochemistry by their metabolic pathway including oxidation, reduction, and mobilization reaction that highly regulates arsenic speciation in our environment. Herein, we further study the microbiological (bacteria, fungus \& higher plant) population of ground waters with references various psycho-chemical parameters of ground water particularly arsenic (As) concentration.
\end{abstract}

Keywords: Arsenic; Microbiology; Geochemistry; Oxidation

\section{Introduction}

Arsenic contamination in ground water is a critical issue in West Bengal (India) and Bangladesh. Over the few decades, geogenic arsenic was highlighted in many regions of the world [1-4]. The most notable in South \& Southeast Asia where 60 million people are affected by chronic arsenic poisoning [2]. Anthropogenic activities (fertilizer, arsenical pesticides, wooden poles preservative agents, mining waste, waste sewage sludge, and coal burning) and well drilling mobilize arsenic into the environment $[2,4,5]$. In Bengal Delta Plain (BDP), several biogeochemical process are also involved (i.e. chemical \& redox change and bacterial Fe (III) reduction) in arsenic mobilization. This sub surface arsenic contamination of ground water not only affects human food chain (rice, vegetables, etc) but also human tissues. This endemic problem is most the important challenge to us $[3,4]$.

\section{Biogeochemical Process}

Many researchers reported the role of iron reducing bacteria in arsenic mobilization [1]. Microbial reduction of Fe (III) by oxidation of organic carbon, leads to microbial decoupling reaction converting $\mathrm{As}(\mathrm{V})$ to, As (III) which is more toxic than $\mathrm{As}(\mathrm{V})$ [1]. Many fecal coliforms also involved in this decoupling reaction [6]. Some different class of fungi are capable of removing toxic arsenic compound from arsenic polluted environments. Most fungus store arsenic inside the cell cytosol with metal binding polypeptides e.g. metallothioneins or phytochelatins also called cell vacuoles. Fungus accumulates arsenic at their stationary phase of growth [7].

\section{i. Depth dependent arsenic mechanism}

Beside having soil of alluvial character, worlds largest Bengal delta plain (BDP) is, also a flood porn zone. Physico-chemical parameters of soil in this region has more pragmatic relation to arsenic mobilization. Many chemical parameters such as $\mathrm{pH}$, Eh, $\mathrm{Na}^{+}, \mathrm{Ca}^{+}, \mathrm{Mg}^{+}, \mathrm{Fe}_{\mathrm{T}}, \mathrm{Fe}$ (II) and also temperature has been reported to be positively co-related to arsenic mobilization [2-4].

\section{ii. Oxidation and reduction process}

The oxidation model demonstrates release of Arsenic from sulphide minerals by the reaction given below [8].

$$
\begin{aligned}
& \mathrm{FeS}_{2}(\mathrm{~S})+7 / 2 \mathrm{O}_{2}+\mathrm{H}_{2} \mathrm{O} \leftrightarrow \mathrm{Fe}^{2+}+2 \mathrm{SO}_{4}{ }^{2}-+2 \mathrm{H}^{+} \\
& \mathrm{FeAsS}(\mathrm{S})+13 \mathrm{Fe}^{3}++8 \mathrm{H}_{2} \mathrm{O} \leftrightarrow 14 \mathrm{Fe}^{2}++\mathrm{SO}_{4}{ }^{2}+13 \mathrm{H}++\mathrm{H}_{3} \mathrm{AsO}_{4}
\end{aligned}
$$

The reduction model of arsenic also called reverse approach of the oxidation model involves co-precipitation of Arsenic with Fe/ Mn/-oxide/ Hydroxide [8]. 


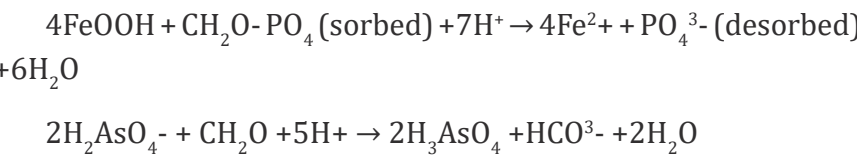

\section{Future Scope}

From the study it can be stated that the arsenic contamination has spread throughout the world and there is an urgency to fight against it. We hypothesize that microbes converts high toxic or carcinogen arsenite [As (III)] to arsenate [As (V)]. Also some applicable technique that can be used to analyze interaction between arsenic microbes (bacteria, fungus \& higher plant) and physiological properties of subsurface and surface biodiversity.

\section{References}

1. Farhana S Islam, Andrew G Gault, Christopher Boothman, David A Polya, John M Charnock et al. (2004) Role of metal-reducing bacteria in arsenic release from Bengal delta sediments. Nature 430(6995): 6871.

2. Ashis Biswas, Santanu Majumder, Harald Neidhardt, Dipti Halder, subhamoy Bhowmick et al. (2011) Groundwater chemistry and redox processes: Depth dependent arsenic release mechanism. Applied Geochemistry 26(4): 516-525.
3. Dipti Halder, Bhowmick s, Biswas A, Chatterjee D, Nriagu J et al. (2012) Risk of Arsenic Exposure from Drinking Water and Dietary Components: Implications for Risk Management in Rural Bengal. Environ Sci Technol 47(2): 1120-1127.

4. Subhamoy Bhowmick, Nath B, Halder D, Biswas A, Majumder S et al. (2012) Arsenic mobilization in the aquifers of three physiographic settings of West Bengal, India: Understanding geogenic and anthropogenic influences. Journal of Hazardous Materials 262: 915923

5. Shengwen Shen, Xing Fang Li, William R Cullen, Michael Weinfeld, $X$ Chris Le (2013) Arsenic binding to proteins. Chem Rev 113(10): 77697792.

6. Alexander van Geen, Ahmed KM, Akita Y, Alam MJ, Culligan PJ et al. (2011) Fecal Contamination of Shallow tube wells in Bangladesh Inversely Related to Arsenic. Environ Sci Technol 45(4): 1199-1205

7. Pornsawan Viscoottiviseth, Nootra Panviroj (2001) Selection of fungi capable of removing toxic arsenic compounds from liquid medium. Research Article, Science Asia 27: 83-92

8. Chatterjee D, Halder D, Majumder S, Biswas A, Nath B et al. (2010) Assessment of arsenic exposure from ground water and rice in Bengal Delta Region, West Bengal, India. Water Research 44(19): 5803-5812.

\begin{tabular}{|l|}
\hline \multicolumn{1}{|c|}{ Your next submission with Juniper Publishers } \\
will reach you the below assets \\
- Quality Editorial service \\
- Swift Peer Review \\
- Reprints availability \\
- E-prints Service \\
- Manuscript Podcast for convenient understanding \\
- Global attainment for your research \\
- Manuscript accessibility in different formats \\
( Pdf, E-pub, Full Text, Audio) \\
- Unceasing customer service \\
Track the below URL for one-step submission \\
https://juniperpublishers.com/online-submission.php \\
\hline
\end{tabular}

